\title{
Gaslighting in Employee Remuneration As an Element of Management Culture in Modern Russia \\ O.V. Sukhova
}

Ural State Law University, Yekaterinburg, Russian Federation

\section{Abstract}

This article analyzes the management culture of Russian companies, especially one of the methods of managing employees' labor behavior - gaslighting. Gaslighting is a manipulation of human behavior based on psychological violence. To get the conclusion that gaslighting has become the norm in the management culture of Russian companies, the author analyzed the term "gaslighting" and compared this phenomenon with the situations in the corporate management strategies of various company managers. The purpose of the article is to analyze elements of the management culture of Russian companies, identify destructive manipulations of labor

Corresponding Author:

O.V. Sukhova

klass2503@mail.ru

Published: 21 January 2021

Publishing services provided by Knowledge E

(c) O.V. Sukhova. This article is distributed under the terms of the Creative Commons

Attribution License, which permits unrestricted use and redistribution provided that the original author and source are credited.

Selection and Peer-review under the responsibility of the XXIII International Conference Conference Committee. behavior, their impact on the level of staff remuneration, and assess the consequences of gaslighting in staff remuneration on the company's viability and stability of its management system. Based on the generalization results, the author concludes that the use of specific techniques in company management causes significant harm, although, at first glance, one can talk about a positive effect, especially about saving financial resources. The regular creation of failures in the form of setting tasks that cannot be completed, due to the lack of real and objective opportunities, forms employees' "learned helplessness syndrome". Often, gaslighting is used when calculating employees' salaries and is integrated into the payment system. The inability to get the desired remuneration reduces employees' self-esteem, resulting in a loss of interest in the work. In this case, the situation when the employee is informed that the reason for his or her failures lies in himself/herself is especially harmful and dangerous (he or she did not try hard enough, did not make enough effort, and did not have the right qualifications or experience). The employee is convinced that something is wrong with him or her, comparing themselves with others who achieve and earn. In this case, the manager loses control over the situation with such a team member. When such employees become critically numerous in the company, one can talk about the loss of control over the company, which can lead to its degradation and decline.

Keywords: motivation, manipulation, labor behavior management, incentive system, management style, national traditions, employee mentality.

\section{Introduction}

Nowadays, gaslighting has become an essential element in management culture. ManipG OPEN ACCESS 
almost any organization. This phenomenon in itself is destructive and causes harm to employees in this situation, but the damage to the company itself is also enormous.

The purpose of the article is to analyze elements of the management culture of Russian companies, identify destructive manipulations of labor behavior, their impact on the level of staff remuneration, and assess the consequences of gaslighting in staff remuneration on the company's viability and stability of its management system.

\section{Methodology and Methods}

The essence of gaslighting in open sources is usually reduced to the following - it is a form of manipulation of behavior with the help of psychological violence, when the victim is convinced of his or her failure and inability to do anything, bias to what is happening [1]. Any incentive system in an organization is essentially a system of manipulation of labor behavior [2]. A transparent incentive system, in which the indicators are not ambiguous, is achievable by the majority of participants and is intended not to prove the inferiority of those who did not get what they wanted, but to give the company's employees and the company itself an opportunity to earn money. At the same time, in Russia, there are trends in the management practice of manipulating labor behavior based on the psychological violence of employees. When building remuneration systems, indicators that are almost impossible to implement are laid. Sometimes this becomes impossible simply because the employer has not provided necessary working conditions to achieve these indicators. At the same time, in order to prevent adverse emotional reactions of employees, the company's culture circulates legends "about the potential laziness of employees", about the need to achieve success (key performance indicators - KPIs), and the "carelessness" of most employees is reinforced with a loud demonstration of the success of some company employees.

To achieve this goal, the author analyzed general information on the culture of power and management $[3,4]$, the motivation of labor behavior $[5,6]$, as well as features of management psychology and manipulations [7] used in modern management practice in Russia. The results of the theoretical analysis, as well as the practical management experience of the author, allowed making the author's generalization and assessment of the current situation. 


\section{Results and Discussion}

The culture of managing labor behavior in Russia has its specifics and has preserved many national traditions from the past, for example, any manager at all levels of management requires such a national trait as "tolerance". The head of all levels of management, including state, could always count on patience during difficulties, so extreme measures in management decisions can be seen at all times and all levels of management; "the people will suffer, the people will understand" is the natural expectation of the head. The author sees that this feature of management culture is based on a high level of religiosity in pre-revolutionary Russia. The revolution at the beginning of the last century eradicated many religious postulates, but widespread "tolerance" proved to be in demand in the post-revolutionary period, during the war, and during the reconstruction of the country in the post-war periods. Industrialization and perestroika also suggested the use of "patience" as a national characteristic of a Russian person. The "patience" of a Russian worker also came in handy during the formation of the "market economy". Widespread non-payment of wages, impoverishment of employees were typical of the 1990s. At the same time, during this period, there was a sharp increase in the number of millionaires, and large capitals were born. Besides, according to the author, it was the mass manipulation of the national qualities of the population that made it possible for substantial capital to be born in Russia. Patience, non-conflict, and a respectful attitude towards work, which was cultivated throughout the Soviet period, became a national treasure and allowed the business of that period to increase its capital.

Of course, over time, management culture has also changed, and even the tools of destructive manipulation of labor behavior have become more sophisticated.

As part of this article, the author would like to take a separate look at such a tool in the management system as management of employee performance using wages and the use of gaslighting in incentive systems.

Labor efficiency, the effectiveness of organizations in general, and each employee, in particular, is a national idea of the last time. Most companies use modern payment systems based on KPIs. For public sector employees, a particular version of the employment contract was developed - an effective contract, where key performance indicators became fundamental.

The need to spend the available funds correctly has become a logical and final postulate in the company management and the state as a whole. Here one can see a change in management thinking and the mass introduction of the idea that revenues 
should exceed expenses into management culture, which determines the management quality. All other management quality criteria are considered secondary.

It is worth noting one interesting point, in practice, the presence of other criteria was not denied, only when calculating the quality of work, it is economic efficiency that could serve as an assessment of the employee's work.

Thus, when declaring any options for evaluating labor behavior in practice, only the financial benefit remains significant. It is particularly difficult to adopt such a management culture in social organizations, the officially stated goal of which is the realization of social and spiritual benefits, which are not associated with profit. However, it is the financial benefit that becomes the primary criterion for success in the employee's activities.

Putting KPIs as the only successful motivation system in the management culture of all companies cannot be a negative phenomenon in itself. The system gets a negative connotation when employees get unreachable tasks in their work. In the author's opinion, situations, when an employee is unable to achieve the tasks assigned for various reasons, put him or her in a behavioral deadlock. The lack of working conditions, limited company resources, and often the lack of authority get in the way of achieving the necessary indicators, as a result of which the employee does not have a real opportunity to perform this task. In this case, as a rule, there may be a situation when other employees, having access to limited company resources, perform tasks and receive the expected remuneration. The futile attempts of employees to get what they want from time to time fix the belief that something is wrong with them, they are "losers". Later, the "learned helplessness syndrome" develops [8].

In this case, especially harmful and dangerous is the situation when the employee is explained that the reason for his failures lies in himself. He did not try hard enough, did not make enough effort, did not have enough qualifications, experience, etc. The employee is convinced that something is wrong with him, and others achieve and earn. The author refers to this as "gaslighting", which is used in labor relations. Setting barriers to achieving labor results, as well as not accepting managerial responsibility, shifting it to an employee is a classic example of gaslighting in relationships.

Another striking example of the use of gaslighting in management can be an example of calculating the average salary in the country and in the regions. The media publish reports in which the average salary is a decent figure. For example, the official website of the Ministry of the Economy and Territorial Development of the Sverdlovsk Region reported that the average salary according to the data of Sverdlovskstat was 37,209.7 rubles, which was 105.7\% growth to the salaries level in 2018 [9]. However, in an interview 
with the author of the article, participants in various economic systems comment on the average salary of $15,000-20,000$ rubles. At the same time, each of them is convinced that "probably there is such a salary somewhere and something is wrong with him or her personally". Disputes about wages in the media are raised regularly, but all representatives of the state administration comment that individuals deliberately distort information, and "in fact, the figures correspond to reality".

\section{Conclusions}

Absolute trust in the authorities, patience, and ingenuousness as national traits of character formed the basis of the mentality of a Russian worker and allowed many negative phenomena in power to form and strengthen, such as cronyism, bureaucracy, and corruption. The disconnect between rhetoric and action of the head, which is one of the classic gaslighting techniques, is also a repeated phenomenon in the corporate culture of many companies today. The appointment of an employee who often has neither the authority nor the organizational capabilities to perform the indicators set as the culprit of negative consequences in the organization's activities is a negative phenomenon that causes a drop in the level of interest in the results of work in future periods, loss of confidence in the manager, and in extreme cases, loss of faith in their strength and capabilities. This is especially painful when it affects the employee's salary. Several failed situations force the employee to abandon the need to take the initiative in achieving the goals set for managers. The incentive system and the promise of good earnings is perceived as a "game for the insiders" and a declaration of empty promises for everyone else. The author sees that this situation becomes disastrous as the loss of motivation to work becomes a factor that reduces the quality of the labor force. Even after changing a company, the employee acts based on negative experience accumulated in previous companies. Disbelief and distrust prevent him or her from becoming a full-fledged member of a new team. After working in several companies, an employee gains absolute inertia to all managerial influences, where he or she is consolidated in the idea that "everywhere is the same and everyone is deceived". Thus, having accumulated a critical mass of such employees, the company loses control over its management. All management actions in such companies fall into the silent sabotage of employees. This is what the author sees as the reason for the refusal of modern employers from older workers. Their level of distrust can lead to a passive attitude towards work, and in conditions of resource savings, the cost of each employee becomes significant in the cost estimates of each company. Therefore, 
employers often, other things being equal, will choose a young employee who still has trust and expectations.

Thus, gaslighting in staff remuneration has become a widespread phenomenon. It is a national feature in management culture. Undoubtedly, at first, the use of gaslighting in payment seems to the author to be a useful tool for managing the company's costs. However, the consequences, in the form of loss of manageability of labor behavior, as well as a decrease in employees' loyalty to the employer and in general to labor remuneration, can become a national disaster when a critical mass of such employees accumulates in the total number of the working population of the country.

\section{References}

[1] Shlaina, V. M. (2016). Socionika v reshenii problem gazlajtinga [Socionics in solving the problems of gaslighting]. Menedzhment $i$ kadry: psihologiya upravleniya, socionika i sociologiya, vol. 11-12, issue 167-168, pp. 74-75.

[2] Suhova, O. V. (2014). Paradoksy upravleniya sovremennosti. Motivaciya ili manipulyaciya? [The paradoxes of modern management. Motivation or manipulation?]. Diskussiya, vol. 2, issue 43, pp. 55-58.

[3] Mitin, A. N. (2001). Kul'tura vlasti i upravleniya [Culture of power and management]. Ural'skaya akademiya gosudarstvennoj sluzhby. pp. 490-498.

[4] Harchev, V. V. (2014). Modeli upravlencheskoj kul'tury: nerazryvnaya svyaz' vlasti, ekonomiki i upravleniya [Management Culture Models: An Inextricable Link between Power, Economics, and Management]. Social'no-gumanitarnye znaniya, vol. 12, pp. 155-160.

[5] Vedernikov, M. D., Poplavskij, E. M. (2013). Osobennosti motivacii trudovogo povedeniya rabotnikov $v$ sovremennyh usloviyah [Features of motivation of labor behavior of workers in modern conditions]. Problemy ekonomiki i menedzhmenta, vol. 5, issue 21, pp. 3-5.

[6] Ponomareva, I. K., and Akif'ev, I. V. (2018). Otechestvennyj vzglyad na motivaciyu upravlencheskogo personala [Domestic view on the motivation of management personnel]. Voprosy upravleniya, vol. 2, issue 32, pp. 147-152.

[7] Bardier, G. L. (2018). Psihologiya upravleniya [Domestic view on the motivation of management personnel]. Vestnik Omskogo universiteta. Seriya "Psihologiya", vol. 3, pp. 27-32.

[8] Volkova, O. V. (2013). Teoretiko-metodologicheskij analiz issledovanij vyuchennoj bespomoshchnosti: aktual'nost' psihosomaticheskogo podhoda [Theoretical and 
methodological analysis of studies of learned helplessness: the relevance of the psychosomatic approach]. Sibirskoe medicinskoe obozrenie, vol. 4, pp. 43-47.

[9] Information about the average monthly salary in the Sverdlovsk Region in January 2019. Retrieved February 15, 2020 from http://economy.midural.ru/content/ informaciya-o-srednemesyachnoy-zarabotnoy-plate-v-sverdlovskoy-oblasti-vyanvare-2019-goda. 